\title{
Role of Gene Therapy in Pancreatic Cancer-A Review
}

\author{
Mizuho Sato-Dahlman ${ }^{1,+}$, Keith Wirth ${ }^{1,+}$ and Masato Yamamoto ${ }^{1,2,3,4, *}$ \\ 1 Department of Surgery, University of Minnesota, Minneapolis, MN 55455, USA; satom@umn.edu (M.S.-D.); \\ wirth129@umn.edu (K.W.) \\ 2 Masonic Cancer Center, University of Minnesota, Minneapolis, MN 55455, USA \\ 3 Stem Cell Institute, University of Minnesota, Minneapolis, MN 55455, USA \\ 4 Surgery BTR, MMC 195, 8195F, 420 Delaware St SE, Minneapolis, MN 55455, USA \\ * Correspondence: yamam016@umn.edu; Tel.: +1-612-624-9131; Fax: +1-612-624-9080 \\ + These authors share equal contribution to authorship of this paper.
}

Received: 24 February 2018; Accepted: 30 March 2018; Published: 3 April 2018

\begin{abstract}
Mortality from pancreatic ductal adenocarcinoma (PDAC) has remained essentially unchanged for decades and its relative contribution to overall cancer death is projected to only increase in the coming years. Current treatment for PDAC includes aggressive chemotherapy and surgical resection in a limited number of patients, with median survival of optimal treatment rather dismal. Recent advances in gene therapies offer novel opportunities for treatment, even in those with locally advanced disease. In this review, we summarize emerging techniques to the design and administration of virotherapy, synthetic vectors, and gene-editing technology. Despite these promising advances, shortcomings continue to exist and here will also be highlighted those approaches to overcoming obstacles in current laboratory and clinical research.
\end{abstract}

Keywords: pancreatic cancer; pancreatic adenocarcinoma; virotherapy; oncolytic; non-viral vector; RNA interference; siRNA

\section{Introduction}

Pancreatic cancer is now the third leading cause of cancer-related death in the United States, with pancreatic ductal adenocarcinoma (PDAC) representing the majority of these cases [1]. Despite a steady increase in survival for most cancers over the decades, the 5-year survival of PDAC remains essentially unchanged at $8 \%$ [1]. This dismal prognosis is due to a number of factors including late presentation, aggressive tumor dissemination, and lack of effective systemic therapies.

Surgical resection with adjuvant chemotherapy remains the mainstay of curative treatment; however, at the time of diagnosis, it is estimated that only $20 \%$ of patients are eligible for resection [2]. With the addition of adjuvant chemotherapy, median survival of resectable cases is roughly 2 years, reaching a median of 28 months in a recently published trial [3]. A number of chemotherapeutic agents, particularly in combination, have been tested in the treatment of PDAC including 5-flourouracil, gemcitabine, capecitabine, nab-paclitaxel, and FOLFIRINOX (5-FU, irinotecan, and oxiplatin) [4-6]. While the results of these studies are certainly promising, the survival benefits are typically in the order of months. In addition, a number of factors including patient comorbidity, postoperative complications, and rapid disease progression affect the ability for patients to complete these prescribed regimens, with utilization of adjuvant chemotherapy following pancreatectomy being as low as 50\% in some populations [7]. Taking into account these outcomes following what is titled a curative resection, a paradigm shift in the treatment of PDAC has been suggested, treating this as a systemic disease from the time of diagnosis [8]. 
These data highlight the current challenges which novel therapeutics for PDAC must address: (1) Improved targeting; (2) Less side effects with improved tolerance; and (3) Treatment of PDAC as a systemic disease. A promising area of research which may provide these benefits is that of gene therapies, specifically virotherapies, novel gene vectors, gene-editing technology, and RNAi therapy, which will be explored in this review. The therapies outlined here are summarized for refrence in Table 1.

Table 1. Various therapeutic proteins coupled with viral therapies.

\begin{tabular}{|c|c|c|c|}
\hline Name & Vector/Delivery System & Route of Delivery * & References \\
\hline \multicolumn{4}{|l|}{ Virus } \\
\hline ONYX-015 & $\begin{array}{l}\text { Conditionally replicative adenovirus (CRAd) mutant dl1520, lacking E1B } \\
\text { region } \\
\text { Mechanism: Selective replication in cancer cells with mutated p53 }\end{array}$ & IV & [9] \\
\hline ОВР-301 & $\begin{array}{l}\text { CRAd-E1A-mutation type } \\
\text { Mechanism: Expresses E1A under the control of the human telomerase } \\
\text { reverse transcriptase (hTERT) promoter }\end{array}$ & PC & [10] \\
\hline AduPARE1A & $\begin{array}{l}\text { CRAd-E1A-mutation type } \\
\text { Mechanism: Expresses E1A gene under the control of the urokinase-type } \\
\text { plasminogen activator receptor (uPAR) promoter }\end{array}$ & IV & {$[11,12]$} \\
\hline Cox2CRAd & $\begin{array}{l}\text { CRAd-E1A-mutation type } \\
\text { Mechanism: OAd controlled by cyclooxygenase- } 2\end{array}$ & IT & [13] \\
\hline T-VEC & $\begin{array}{l}\text { Herpes simplex virus expressing GM-CSF } \\
\text { Mechanism: Sensitize the tumoricidal effects of chemotherapeutic agents } \\
\text { (e.g., 5-FU) and radiotherapy }\end{array}$ & IT & [17] \\
\hline Reolysin & $\begin{array}{l}\text { Unmodified oncolytic reovirus } \\
\text { Mechanism: Replication in Ras-activated cancer cells, trial in combination } \\
\text { with gemcitabine }\end{array}$ & IV & [18] \\
\hline HF10 & $\begin{array}{l}\text { Unmodified oncolytic herpes simplex virus } \\
\text { Mechanism: Selective replication in cancer cells }\end{array}$ & IT & {$[19,20]$} \\
\hline VCN-01 & $\begin{array}{l}\text { Replication-competent adenovirus } \\
\text { Mechanism: Selective replication in cancer cells with defective RB pathway, } \\
\text { hyaluronidase expressing }\end{array}$ & IT & [21] \\
\hline AEG35156 & Antisense oligonucleotide targeting X-linked inhibitor of apoptosis (XIAP) & IV & [25] \\
\hline ATu027 & $\begin{array}{l}\text { siRNA targeting protein kinase } 3 \text { (PKN3) mRNA utilizing a liposomal } \\
\text { complex (AtuPLEX) carrier }\end{array}$ & IV & {$[26,27]$} \\
\hline si-G12D-LODER & $\begin{array}{l}\text { siRNA drug targeted mutant KRAS, utilizing biodegradable polymeric } \\
\text { matrix }\end{array}$ & IT & [28] \\
\hline \multicolumn{4}{|l|}{ DNA } \\
\hline CYL-02 & $\begin{array}{l}\text { Plasmid DNA encoding for somatostatin receptor subtype } 2 \text { (SSTR2), } \\
\text { deoxycytidine kinase (DCK), and uridylate monophosphate kinase (UMK) }\end{array}$ & IT & {$[29,30]$} \\
\hline BC-819/DTA-H19 & $\begin{array}{l}\text { Plasmid DNA encoding the diphtheria toxin-A chain under the regulator of } \\
\text { the H19 promoter }\end{array}$ & IT & [31] \\
\hline SGT-53 & $\begin{array}{l}\text { Plasmid DNA encoding normal human wild-type p53 utilizing cationic } \\
\text { liposome carrier }\end{array}$ & IV & [32] \\
\hline
\end{tabular}

* IV-intravenous, IT-intratumoral, PC-preclinical, not yet tested in vivo.

\section{Virotherapies}

Virotherapy strategies provide new options for treatment of various cancers, including pancreatic cancer. Oncolytic virotherapy is one of the most promising anti-cancer agents and it has been employed for antitumoral potency via its intratumoral amplification and its strong oncolytic effect. Among them, 
herpes simplex virus (T-VEC, Talimogene laherparepvec, also known as OncoVEX GM-CSF) is showing positive outcomes in clinical trial and was recently approved by the US Food and Drug Administration (FDA) for use on unresectable melanoma [17,33]. Thus, oncolytic virotherapy is becoming increasingly popular for the treatment of many different forms of cancer.

\subsection{Replication-Based Control Oncolytic Adenoviruses}

Many groups, including our own, have used adenoviruses (Ads) as a basis for the development of oncolytic agents because of the many clinically beneficial attributes and the existing rich knowledge of the adenovirus vector system [34,35]. Adenovirus vectors are known for their high in vivo gene-delivery efficiency [36], a very desirable trait and a key requirement for antitumor effect. In contrast to enveloped viruses released from cells through budding, the lytic life cycle of Ad involves the infection, replication in, and eventual destruction of host cells [37]. Recent studies also suggest that Ads have the ability to induce autophagy in cancer cells [38]. Virus-induced autophagy correlates positively with virus replication and oncolytic cell death. This characteristic is directly exploitable for oncolysis. The Ad is genetically stable, and the virus genome does not integrate into the target cell genome, meaning there is no genotoxicity [36].

Conventionally, adenoviral gene therapy has been performed in a replication-deficient system to avoid the possibility of toxicity resulting from adenoviral replication. To improve the antitumor efficacy without sacrificing specificity and safety, conditionally replicative adenoviruses (CRAds) have been developed. The basic concept of CRAds as oncolytic agents is that viruses replicate in tumor cells only and the subsequent lateral spread of progeny virus to surrounding tumor cells facilitates a dramatic amplification of the therapeutic effect, leaving surrounding normal cells unharmed. To date, two types of CRAds have been designed to replicate selectively in tumor cells: mutation-based and cancer-specific promoter-based.

The first type of CRAds involved some mutations or deletion in the E1 region, which allowed replication only in specific tumors which can compensate for the loss of function due to mutation [9,39,40] (Figure 1A). The Ad mutant dl1520 (or ONYX-015) lacks the E1B region and this defect was initially expected to allow replication only in the cells with mutated p53 gene [9]. However, later studies suggested that d11520 may not be entirely dependent upon p53 status. One of the studies has suggested that E1B is involved in cell cycle regulation and this E1B function is not essential in some cancer cells [41]. Also, $\mathrm{Ad} \Delta 24$ is another E1A-mutation-type CRAd which theoretically restricts replication to cancer cells with mutated pRb [40]. Also, we have recently generated new CRAds that are targeted to Human Papilloma Virus (HPV)-positive head and neck squamous cell carcinomas (HNSCC). These CRAds included small deletions in the E1A region of the genome $(\Delta 24$ or CB016) intended to allow for selective replication in HPV-positive cells, and they demonstrated excellent in vitro and in vivo therapeutic effects [42].

The second type of CRAds are driven by tumor-specific promoters (TSPs). This type of CRAds relies on cancer-specific, promoter-controlled transcription of the E1 region (Figure 1B). Since the E1A protein is necessary for Ad replication, promoter-controlled Ad can replicate only in cells where the controlling promoter is active. For example, OBP-301 was engineered to express E1A under the control of the human telomerase reverse transcriptase (hTERT) promoter, which is activated in various types of human cancer cells, including pancreatic cancer [10]. AduPARE1A virus drives the E1A gene under the control of the urokinase-type plasminogen activator receptor (uPAR) promoter and showed its selective replication and its strong antitumor activity in pancreatic cancer models [11,12]. Our group developed OAd controlled by cyclooxygenase-2 (Cox-2), Cox2-CRAd, for gastrointestinal cancers (e.g., pancreatic cancers [13], esophageal adenocarcinomas [43], and peritoneal dissemination of gastric cancer [44]). 
A. Deletion /Mutation type CRAd (i.e. Onyx-015, AdD24)

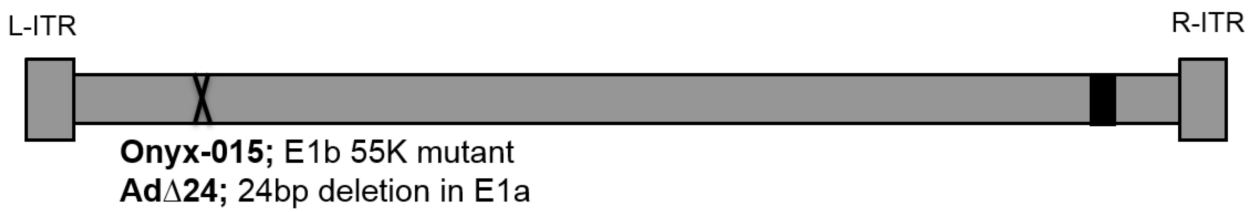

B. Selective promoter-based CRAd

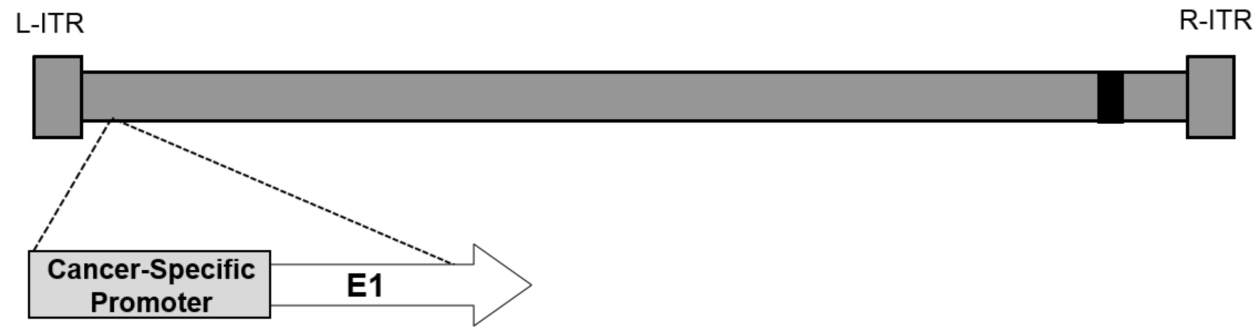

(i.e. OBP-301, AduPARE1A, Cox2CRAd )

Figure 1. Control mechanisms of oncolytic adenovirus. (A) Deletion type Conditionally Replicative Adenovirus (CRAds): this type of CRAd has a mutation/deletion in a region crucial for viral replication. While cancer cells possess the cellular environment to compensate for the missing function of the virus, normal cells do not have that capability. For example, ONYX-015 (dl1520) and Ad $\Delta 24$ were designed to replicate only in p53 and pRb mutated cells, respectively; (B) Selective promoter-based CRAd: A tumor/tissue-specific promoter controls the expression of viral genes crucial for replication. As a result, the virus can replicate only in cells in which the promoter is active. By using a promoter with a tumor-ON/normal cell-OFF profile, the replication can be restricted to cancer cells.

\subsection{Enhanced Adenovirus Transduction}

Adenoviral infection is mediated by precise protein-protein interactions which permit the configuration of stringent transductional targeting systems, rather than lipid membrane fusion. However, the OAd infectivity in many cancers (e.g., gastrointestinal cancers, pancreatic cancers, esophageal adenocarcinomas, ovarian cancer) is extremely low due to poor expression of the adenoviral primary receptor (Coxsackie adenovirus receptor, CAR) [43,45]. Therefore, it is reasonable to develop a vector system that can transduce the target cells via another receptor. In order to solve this issue, our lab and several others have incorporated CAR-independent infection capabilities into OAd, as shown in Figure 2. Since the discovery that the "knob" domain within the Ad wild-type fiber region is responsible for CAR binding (Figure 2A), it has become a major target for infectivity enhancement. There are several ways to generate an infectivity-enhanced OAd.

One of the most successful extrinsic binding motifs for infectivity enhancements is the incorporation of the RGD-4C motif into the HI-loop of the fiber-knob region [46,47] (Figure 2B). The RGD-4C motif is a partial peptide sequence of fibronectin identified by phage library screening [48]. Considering paucity of CAR expression in many cancer cells, effective transduction of CAR-negative cells is important for clinical usage of oncolytic adenoviruses. When it was incorporated into the HI-loop of the fiber-knob region, the Ad vector showed CAR-independent infection of the target cells. Also, OAd with this motif showed an improved cytocidal effect in CAR-negative cancer cell lines in vitro and in vivo $[45,49]$.

Most Ad vectors to date are based on subtype 2 or 5 . Both of them are using CAR for binding and run into the problem of poor transduction efficiency in cancer cells. Interestingly, there are other serotype Ad vectors that do not use CAR as their primary receptor. For example, Ad35 uses CD46 [50], and Ad3 uses desmogrin-2 and CD46 as its receptor for initial binding [51]. Thus, the infection of these viruses is CAR-independent. There are several more approaches for changing tropism of adenoviral 
vectors. One approach is to make a vector fully based on alternate subtype vectors (Figure 2C), another is to design an Ad2/5-based vector with an alternate subtype's binding domain incorporated (chimeric or mosaic) (Figure 2D,E), and the other approach is a bridging molecule-based method, and targeting Ad by Ad library screening (Figure 2F). Switching subtype method has the advantage that all parts of the capsid consist of alternate subtype Ad proteins such as Ad3, resulting in distribution assumed to be identical to the parental virus. However, there is a risk of reduced virus replication and cytocidal effect in this approach because the other subtype's oncolysis is not necessarily as strong as that of $\mathrm{Ad} 2 / 5$. As for the bridging molecule-based method, it can achieve the precise selectivity embodied by employing a high affinity/specificity antibody (Ab), or by using a specific binding motif for the target moiety expressed on the cell surface [52-54]. While promising, it is impractical to incorporate the bridging molecule into an OAd system because effective incorporation of bridging molecules into progeny viruses is not easy [13]. In recognition of this fact, chimeric fiber approaches such as Ad5/3 (Ad5 vectors with the fiber-knob domain of Ad3) are more frequently applied for OAds, and chimeric OAds displays improved gene delivery and antitumor efficacy in many preclinical studies $[43,49,55-57]$.
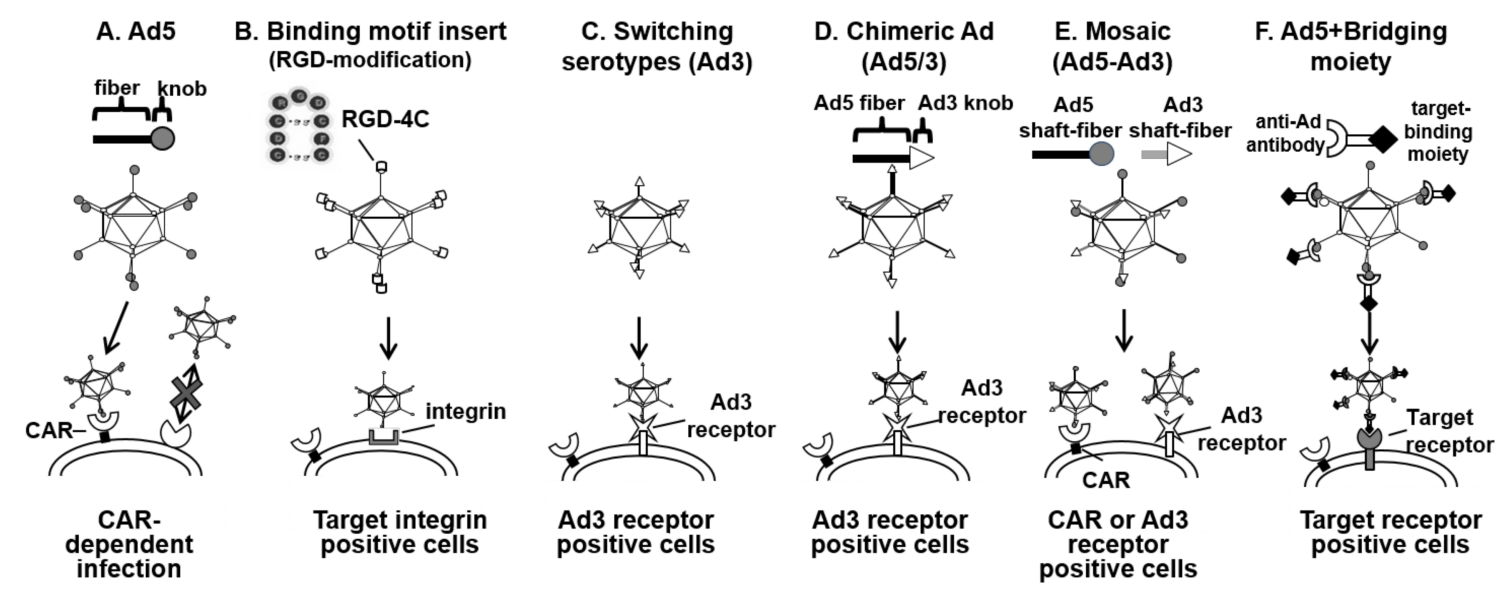

Figure 2. Modification of adenovirus to achieve Coxsackievirus and adenovirus receptor (CAR)-independent transduction. To achieve CAR-independent transduction, several modification strategies have been employed in adenovirus. (A) Poor infectivity of CAR-negative cells with conventional Ad system; (B) fiber modification; (C) switching serotypes; (D) chimeric; (E) mosaic; and (F) bridging molecule-based targeting.

Additionally, ColoAd1 (also known as enadenotucirev, EnAd), a complex and highly potent chimeric Ad3/Ad11p virus, was generated by a novel "directed evolution" approach for its ability to kill colorectal cancer cells [58]. The viral Ad11p capsid is more resistant to elimination by human serum and blood cells than Ad5 [59] which may provide an advantage for systemic delivery. ColoAd1 virus is currently undergoing several early-phase clinical trials (NCT02028442 and NCT02028117) [60].

Although incorporation of several targeting motifs has been reported to increase the infectivity of replication-deficient Ad in pancreatic cancer cells [61-63], the success rate of incorporating pre-identified targeting motifs into OAd has been low. To address this issue, we recently developed the high-throughput screening system using a high-diversity Ad library ( $>10^{10}$ diversity) [14]. This system employs an Ad library with seven random amino acids instead of the CAR-binding domain in the adenoviral fiber-knob region AB-loop [14]. Using this high-diversity library, we successfully isolated potent mesothelin-targeted OAd by replication-based screening [14]. Mesothelin (MSLN) is a cell surface glycoprotein that is highly expressed on pancreatic cancer, ovarian cancer, and mesothelioma [14,15]. The virus with the newly isolated MSLN-targeted OAd showed dramatic selectivity for MSLN-expressing pancreatic cancer cells in vitro and in vivo. The intravenously injected MSLN-targeted OAd showed an impressively strong antitumor effect, which was equivalent or 
stronger than that of intratumoral injection. Regarding systemic treatment, most systemic adenovirus therapies have been limited due to diverse factors such as liver sequestration, neutralizing antibody interactions in blood, elimination by the immune system, and physical barriers in tumors. To overcome these issues, oncolytic therapy mandates more efficient and selective gene delivery and needs to embody sufficient antitumor effect even with limited initial delivery to the tumor location. In this point, our data indicate the possibility of systemic therapy with cancer-targeted OAd by selective infection mediated. Also, Dr. Aoki's group has constructed an adenovirus library displaying random peptides in the HI loop on the fiber knob, and identified a pancreatic cancer-targeting sequence by screening with this adenovirus library [64]. Subsequently, they generated promoter-controlled pancreatic cancer-targeted OAd that displayed the targeting sequence on the fiber knob of survivin promoter-regulated OAd (AdSur-SYE). This virus showed a much higher gene transduction efficiency and strong antitumor efficacy in pancreatic cancer with intratumoral infection [16].

In this sense, the library screening technology may have broad implications for the development of targeted gene delivery approaches.

\subsection{Therapeutic Gene-Expressing Vector}

A reasonable approach to strengthen the antitumor effect of the OAd is expressing a transgene with an antitumor effect from the oncolytic virus. This approach has been taken in a wide variety of oncolytic viruses including Ad and vaccinia [65,66]. One interesting example with Ad is interferon (IFN)- $\alpha$. It has been known that IFN- $\alpha$ has a strong antitumor effect and has the ability to sensitize the tumoricidal effects of chemotherapeutic agents (e.g., 5-FU) and radiotherapy [67-70]. Particularly, in the field of pancreatic cancer, a multicenter phase II trial (5-FU, cisplatin, and IFN- $\alpha$ in conjunction with radiation therapy) confirmed the efficacy of IFN-based chemoradiation for PDAC [67]. However, despite encouraging survival results and immunological data, clinical trials have defined several problems impairing the clinical utility of IFN- $\alpha$ for pancreatic cancer patients: (i) Systemic toxicity of IFN- $\alpha$, and (ii) Insufficient delivery and unsustainable levels of IFN- $\alpha$ in the tumor site due to rapid degradation of the cytokine in blood circulation and low vascularity [71,72].

In the context of IFN expression from Ad, intrinsic class I IFN expression from the infected cancer cells did not hamper Ad replication in the tumor. As a result, OAd with IFN- $\alpha$ showed efficient replication in pancreatic cancer cells $[65,73]$. In this way, OAd with IFN- $\alpha$ has a unique benefit for its application to pancreatic cancers. Moreover, several studies showed that the interactions between OAds and immunomodulatory molecules, such as GM-CSF and interleukin-12 (IL-12), induced an antitumor effect $[74,75]$. Cells of the innate immune system recognize pathogen-associated molecular patterns on the adenovirus. The production of IL-12 and GM-CSF increases, which results in activation of CD4+ and CD8+ T cells. Therefore, even if a small percentage of the cancer cells contains the target molecule for oncolytic adenoviral infection, a local pro-inflammatory response can be elicited to potentiate an antitumor response [76].

In particular, the phase III trial of T-VEC (genetically modified herpes simplex virus expressing GM-CSF) demonstrated improvements in durable response rate and a trend toward improved overall survival compared to GM-CSF alone, which led to the approval by the FDA of its use in advanced melanoma patients [17]. T-VEC is currently being tested in several other clinical trials for the treatment of pancreatic cancer, soft-tissue sarcomas, and head and neck cancer (NCT03086642, NCT03069378 and NCT02626000).

\subsection{Combination Therapy with Oncolytic Viruses}

Combination therapies involving multiple chemotherapies and radiation have been performed in many cancers [77-79]. Likewise, combination therapy is possible and promising with oncolytic virus. For example, the phase II trial of reovirus (Reolysin) in combination with gemcitabine has demonstrated clinical benefit in patients with advanced PDAC (NCT00998322), with promising survival advantage and favorable toxicity profile [18]. Also, a spontaneously mutated herpes simplex 
virus, HF10, is currently in clinical trials for the treatment of pancreatic cancer (Phase I, NCT03252808). The repeated intratumoral injection of HF10 demonstrated that all patients tolerated the treatment well without any observed adverse effects after treatment. The response to treatment was classified as stable disease in three patients, partial response in one patient, and progressive disease in four patients $[19,20]$.

Several studies have reported the combination therapy of gemcitabine and OAd. For example, oncolytic mutants lacking the anti-apoptotic E1B19K gene showed increased pancreatic cancer cell killing in combination with gemcitabine by enhancing drug-induced apoptosis [80]. Ad5/3- $\Delta 24$ was used in combination with gemcitabine in ovarian cancer cells, synergistic interactions were observed that resulted in enhanced cell killing [81]. Moreover, tumor stroma-targeted OAd has been tested in combination with Gemcitabine and Abraxane ${ }^{\circledR}$ (Celgene, Uxbridge, UK) in patients with pancreatic cancer and advanced solid tumors. Two phase I clinical trials with VCN-01 alone or in combination with chemotherapy are currently underway (NCT02045589, NCT02045602). These are designed to investigate the safety and tolerability of three intratumoral injections of VCN-01 (ID NCT02045589) or a single intravenous injection of VCN-(ID NCT02045602). In this study, they used hyaluronidase expressing OAd, it is named VCN-01. VCN-01 is a replication-competent adenovirus specifically engineered to replicate in tumors with a defective RB pathway $(\Delta 24)$, presents an enhanced infectivity through a modified fiber (RGD) and an improved distribution through the expression of a soluble hyaluronidase (PH20) [21].

More recently, the combination therapy of oncolytic viruses and immune-checkpoint inhibitor such as anti- CTLA-4 antibody and anti-PD-1 antibody has demonstrated promising results. For example, Ad5/3- $\Delta 24$-based OAd coding for anti-CTLA4 antibody has been tested in several cancer cell lines, and a direct anti-CTLA-4-mediated pro-apoptotic effect was observed in vitro and in vivo [82]. Also, another approach which is using oncolytic viruses armed with immunostimulatory genes has been reported [22]. They generated LOAd703 which is a designed adenovirus armed with trimerized CD40L and 4-1BBL that activates the CD40 and 4-1BB pathways, respectively. Both in vitro and in vivo, the LOAd703 viruses were able to replicate and kill pancreatic cancer cells via oncolysis. A clinical trial is ongoing to investigate the safety and efficacy of repeated LOAd703 intratumoral injections combined with standard of care in patients diagnosed with pancreatic cancer not eligible for surgery (NCT02705196).

Therefore, the combination of oncolytic virus and immune-checkpoint inhibitor will be an appealing strategy. While it is promising, combinatory approach can sometimes be a double-edged sword because proper evaluation of the combination effect is not that simple: it is crucial to determine appropriate timing, dosing and sequence schedules of each agent. However, once it is established, it may make a big impact for clinical efficacy in various cancers.

\section{Non-Viral Gene Therapies}

While the majority of novel gene therapies described in the literature and here have utilized viral vectors for delivery, non-viral technology has continued to advance with the introduction of novel lipid and polymer technology, as well as gene-editing techniques. The main advantages of non-viral vectors include the potential for less immunogenicity, larger nucleic acid payloads, and relatively easier manufacturing [83].

Barriers to overall gene therapy delivery are well described in a recent review of RNA therapeutics; these include: (1) size and charge of drug; (2) RNase/DNase susceptibility; (3) the reticuloendothelial system of the liver and kidney; (4) immunogenicity; and (5) endocytosis [84]. These challenges have been overcome in a number of interesting ways in pancreatic cancer trials including direct intratumor delivery and sustained release technology [28], various cationic and neutral lipid/liposomes carriers [85], conjugation with synthetic carriers [29], and targeting of receptors to induce endocytosis [32]. The array of potential gene products is substantial, including delivery of 
plasmid DNA, RNA interference technology, and gene-editing systems such as CRISPR/CAS. These applications and future directions will be reviewed in more detail here.

\subsection{RNA Interference}

RNA interference refers to post-transcriptional gene silencing by way of miRNA, siRNA and shRNA. miRNA is of genomic origin and regulates expression of multiple RNA, and major function is translation suppression due to mismatches with the target sequences. siRNA is synthetic in origin and more targeted in effect. The effect of siRNA is considered to be both translation suppression and RNA degradation by RNaseH. shRNA is transcribed from extrinsic DNA, typically a plasmid requiring integration into the host genome [86]. siRNA are those most commonly manipulated in clinical applications due to their more simplistic sequencing and lack of genomic integration [87]. siRNA is a double-stranded RNA molecule typically of 20-30 nucleotides in length that, upon entry into the cytoplasm, is processed by DICER and then associates with the RNA-induced silencing complex (RISC). This complex then binds the complementary target mRNA which is then degraded and "silenced" [88]. (Figure 3) In contrast, antisense oligonucleotides (ASOs) represent single-stranded nucleotide sequences with synthetic modifications to the phosphodiester backbone allowing protection from degradation and enhancing cell entry [84]. ASOs do not require association with cellular machinery for degradation of mRNA [89].

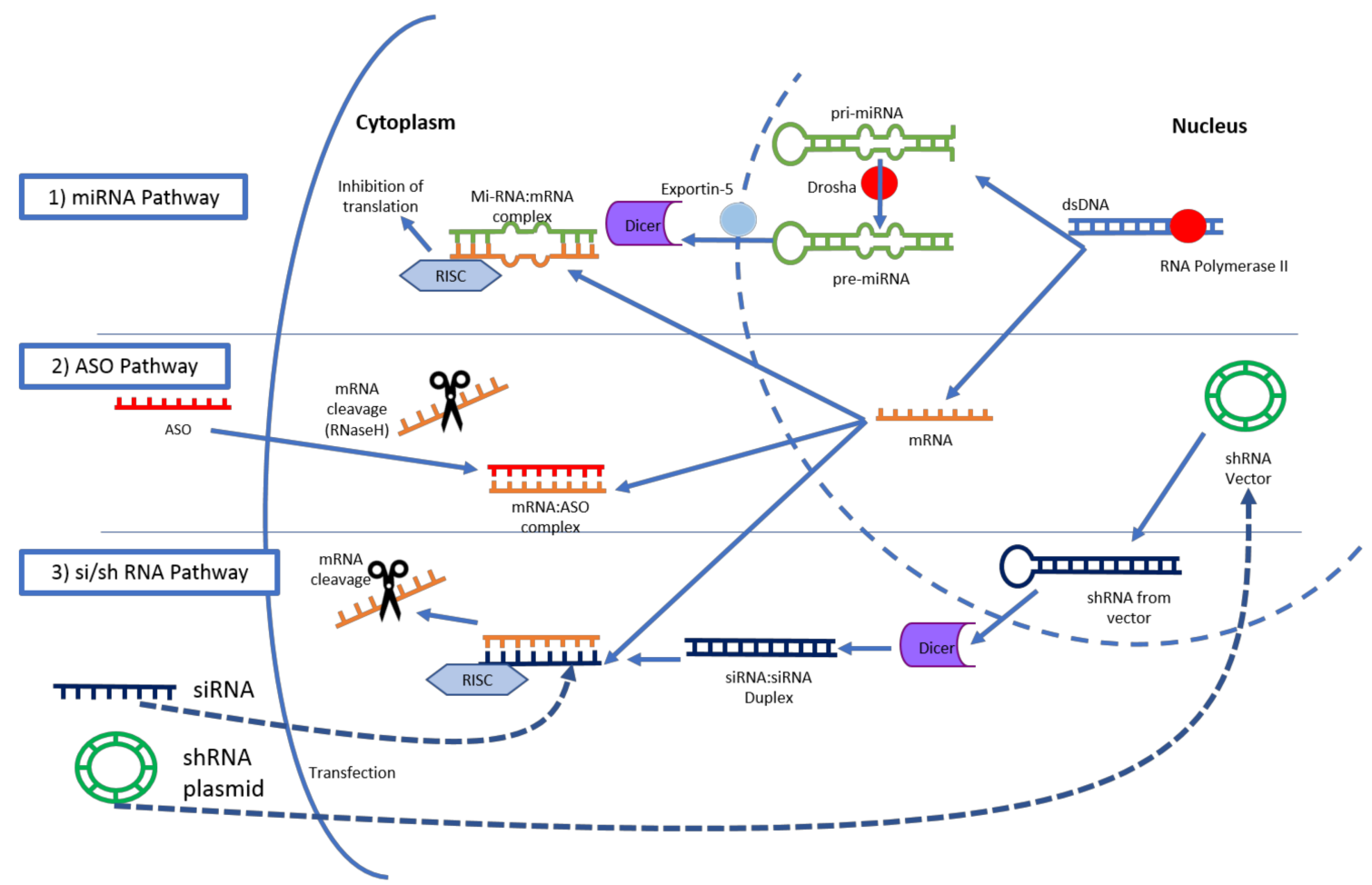

Figure 3. RNA Molecules and respective pathways. (1) miRNA pathway. After processing, one double-stranding miRNA associates with the RNA-induced silencing complex (RISC) complex and inhibits translational expression; (2) Antisense oligonucleotide (ASO) pathway. ASOs enter the cell cytoplasm via described mechanism, bind the target mRNA, and activate intracellular RNase enzyme; (3) siRNA pathway. dsRNA or shRNA are first altered by DICER and become mature siRNA. One strand of siRNA associates with the RISC complex and marks mRNA for degradation.

One of the most attractive features of utilizing RNAi technology is the small size of payload, allowing for the possibility of large amounts of the drugs to be delivered to the target tumor. Most notable in pancreatic cancer tumor architecture, however, is its highly desmoplastic nature, 
with as much as $90 \%$ of tumor volume being made of stromal components [90]. In a study of polymeric micelle nanoparticle size and antitumor activity, drug penetration for pancreatic cancer was noted only in those of a particle size of $30 \mathrm{~nm}$ or less, in contrast to up $400 \mathrm{~nm}$ in the more porous colon cancer models [91]. Despite this difficulty, a number of unique approaches have been tested.

As mentioned earlier, ASOs need not associate with cellular machinery to become functional, and therefore allow for a wider range of chemical modification. ASO modifications include replacement of the nucleotide backbone with phosphothiorated, providing more nuclease stability and enhanced uptake, and 2'-O-methyl modification improving binding and again nuclease resistance [92]. In targeting pancreatic cancer, this has been tested clinically in ISIS-2503, and AEG35156 [23,25]. ISIS-2503 is an ASO-targeting h-ras, and important signaling molecule in PDAC implicated in tumor progression via persistent mitogenic signaling after mutation [93]. This is an example of the phosphothiorated backbone chemical medication. AEG35156 is a recently developed antisense oligonucleotide with the core DNA bases flanked by four 20-O-Me-modified RNA residues [25]. This drug targeted X-linked inhibitor of apoptosis (XIAP), an antiapoptotic protein which strongly inhibits caspases and is overexpressed in a number of malignancies, including PDAC [94]. Both of these ASOs did enter clinical trials, however, with disappointing results. The phase I testing of ISIS in combination with gemcitabine was well tolerated; however, it demonstrated no clinical benefit over gemcitabine alone in the phase II trial $[23,24]$. AEG35156 entered phase I testing, yet failed to show significant clinical activity [25]. As detailed in a recent review of ASO technology, this field is yet developing, and these early results have not yet disrupted the industry, with work on new backbones and conjugates continuing to evolve [92].

Rather than focusing on chemical modification of the sequences themselves, studies of conjugate siRNAs have shown some promising results. In addition to the addition of a liposomal conjugate, the drug ATu027 took an interesting approach to overcoming the difficult tumor penetration in PDAC. Atu027 is a siRNA-targeting protein kinase 3 (PKN3) mRNA utilizing a liposomal complex (AtuPLEX) carrier. PKN3 is a downstream effector of the PI3 kinase pathway, and interference via antisense inhibitors is thought to decrease angiogenesis and metastases via endothelial modulation [26,27]. The liposomal complex carrier includes a cationic lipid and a PEG-lipid, making it particularly effective targeting endothelial cells, rather than the PDAC tumor itself. The phase 1 trial demonstrated safety and tolerance in escalating doses delivered intravenously, with $41 \%$ of patients demonstrating disease stabilizing [85]. Of note in this trial, a wide variety of cancers were included, while the ongoing Phase II trial evaluating Atu027 (NCT01808638) is specific to advanced and metastatic pancreatic cancer.

Finally, rather than taking a systemic approach to drug delivery, administration of si-G12D-LODER in locally advanced pancreatic cancer was focused on direct intratumor delivery and sustained release [28]. This siRNA drug targeted mutant KRAS (glycine to aspartate at codon 12), an early mutation involved in over $95 \%$ of pancreatic cancer cases [95]. This intervention took advantage of a novel delivery system Local Drug EluteR (LODER-Silenseed Ltd. (Modi'in, Israel)), which is a biodegradable polymeric matrix which allows for both protection from degradation and slow stable drug release over the course of months [96]. In this phase 1/2a clinical study of si-G12D-LODER, the matrix was delivered by endoscopic ultrasound (EUS) using a biopsy needle, in a population of patients diagnosed with unresectable, locally advanced adenocarcinoma of the pancreas, or those not fit for surgery. The drug was deemed safe and well tolerated, with a median overall survival of 15.12 months. In those patient whom underwent follow-up CT scan, 10/12 demonstrated stable disease [28]. With some promising results, a randomized Phase 2b study in currently in progress (NCT01676259).

Before moving to DNA therapies, it should be noted that microRNA (miRNA) therapy is certainly being evaluated in the preclinical stages in the treatment of PDAC. miRNAs are a family of 21-25 nucleotide non-coding RNA that are typically transcribed by RNA polymerase II and act to attenuate mRNA translation [97]. A number of miRNAs have been implicated in the initiation and progression of PDAC, regulating key pathways, such as the recently targeting K-ras mutation [98,99]. Unfortunately, 
no miRNA therapeutics have yet entered clinical testing for treatment of PDAC, while some are indeed underway for other gastrointestinal cancers [98].

\subsection{Plasmid DNA}

Delivery of plasmid DNA (pDNA), in addition to the possible mechanisms of RNAi discussed above, offer the ability to transcribe for the replacement of mutated enzymes, suppressed signaling molecules, and for cytotoxic machinery. The notable differences in barriers to delivery of pDNA to RNAi is that of size, charge and target site of action [100]. The most common methods of overcoming these are conjugation to polyplexes such as polyethylenimine (PEI), and lipid complexes. pDNA offers the ability to target some of the key genetic alterations, including loss of tumor suppressor function, and chemoresistance $[90,101]$.

A combination gene therapy, CYL-02, aimed at both loss of function and chemoresistance [29]. This agent targeted the somatostatin receptor subtype 2 (SSTR2), deoxycytidine kinase (DCK), and uridylate monophosphate kinase (UMK.) The SSTR2 receptor is lost in 95\% of PDAC cases, and in vivo administration demonstrated significant inhibition of tumor progression [30,102]. DCK is a key enzyme in gemcitabine metabolism, and loss of expression of this enzyme has been associated with chemoresistance [103]. CYL-02 is a plasmid DNA encoding for both SSTR2 and a DCK:UMK fusion gene. In the phase 1 trial of this product, two intratumoral injections were performed via EUS with standard of care gemcitabine therapy following. This study proved the treatment safe and well tolerated; however, no significant overall survival response was found. It should be noted that the patients demonstrated two distinct responses, with some having significant improvement in progression-free survival [29]. A Phase II trial is now underway (NCT02806687).

An example of cytotoxic machinery delivery is a double-stranded DNA plasmid therapy, BC-819 (also known as DTA-H19), which has also undergone phase 1 testing [31]. BC-819 is a plasmid encoding the diphtheria toxin-A chain under the regulator of the H19 promoter, a gene which is overexpressed in malignancies and typically not transcribed postnatally [104]. Inclusion criteria biopsy specimens with positive markers for H19 expression, and no concurrent chemotherapy. The protocol included twice-weekly injections for two weeks via either EUS or a percutaneous radiographically guided approach with the plasmid and PEI transfectant. The study demonstrated BC-819 safe and an at least partial response in all full-dose patients. Interestingly, 2/9 patients receiving this treatment had tumors which responded significantly enough to deem them surgically resectable [31].

Finally, SGT-53 is a scL nanocomplex pDNA here aimed at regaining a loss of function, encapsulated in a cationic liposome [32]. The gene encoded is for the normal human wild-type p53, a commonly inactivated tumor suppressor gene in pancreatic cancer, among other malignancies, and a target for antitumor technologies [105]. Also unique to SGT-53 is "decoration" of the liposome with anti-transferrin receptor single-chain antibody fragments, allowing for both specificity and internalization in tumor cells [106]. In contrast to many vectors used to deliver this plasmid intratumorally, SGT-53 was systemically delivered via intravenous injection. This phase 1 trial was completed in a population of patients with varying solid tumors and was well tolerated. A high level of transgene expression was noted in tumor biopsies, and importantly not in normal tissue obtained. Also, 7/11 patients demonstrated stable disease, with one tumor being reclassified as operable after treatment [32]. A phase II study of combination SGT-53, gemcitabine, and nab-paclitaxel in metastatic pancreatic cancer is planned (NCT02340117).

\subsection{Gene-Editing Technology}

Recent developments in CRISPR-Cas9 gene-editing technology has been followed with significant enthusiasm for possible therapeutic applications. Without examining the mechanism in great detail, this system offers the ability to cleave desired double-stranded DNA segments from the genome by introducing CRISPR (clustered regularly interspaced short palindromic repeats) sequences marking sites for cleavage by Cas9 (CRISPR associated) protein endonucleases [107]. This surprisingly simplistic 
system has allowed for a number of novel approaches to understanding the natural history of PDAC and also offers potential therapeutics. Current research is mainly focusing on using this system to further investigate the mechanism of known genetic aberrations, and screen for future gene targeting and phylogenetic tracking [108,109]. Genetic disorders and oncologic trials are planned in the clinical realm with the first-in-human case report of injections of cells containing the CRISPR-Cas9 system just last year [110]. Much like the other gene technologies described above, the vectors and delivery mechanisms of this system will certainly face similar obstacles outlined here [111]. Finally, gene editing will require a much higher efficiency of transduction, as compared to oncolytic virus for example, as all aberrant cells must be edited without a significant bystander effect from cytotoxicity [112].

\section{Conclusions}

With pancreatic cancer mortality remaining unchanged over the past decades, and an expectation to surpass breast, colorectal and prostate cancer mortality by the year 2030, there is a clear impetus to develop novel therapies for the treatment of PDAC [113]. It is hoped that this review of gene therapy highlights both the promising future prospects as well as those challenges that must be overcome in the treatment of PDAC. Preclinical work in screening libraries, combination immunotherapies, and the reinvigoration of clinical trials of virotherapy are certainly encouraging. Novel compounds and nanoparticles are continuing to be developed in non-viral vector technology. Finally, the prospect of gene-editing technology to address the malignant transformation at its primary source will be eagerly awaited.

Acknowledgments: This work was partly supported by Award Numbers R01CA196215 (Masato Yamamoto) and R01CA168448 (Masato Yamamoto). Keith Wirth is supported by NIH/NIDDK T32DK108733 (MPI: Yamamoto and Beilman).

Author Contributions: All authors contributed equally to the preparation and editing of this manuscript.

Conflicts of Interest: The authors declare no conflict of interest.

\section{References}

1. Siegel, R.L.; Miller, K.D.; Jemal, A. Cancer statistics, 2017. Cancer J. Clin. 2017, 67, 7-30. [CrossRef] [PubMed]

2. Kamisawa, T.; Wood, L.D.; Itoi, T.; Takaori, K. Pancreatic cancer. Lancet 2016, 388, 73-85. [CrossRef]

3. Neoptolemos, J.P.; Palmer, D.H.; Ghaneh, P.; Psarelli, E.E.; Valle, J.W.; Halloran, C.M.; Faluyi, O.; O'Reilly, D.A.; Cunningham, D.; Wadsley, J.; et al. Comparison of adjuvant gemcitabine and capecitabine with gemcitabine monotherapy in patients with resected pancreatic cancer (ESPAC-4): A multicentre, open-label, randomised, phase 3 trial. Lancet 2017, 389, 1011-1024. [CrossRef]

4. Cunningham, D.; Chau, I.; Stocken, D.D.; Valle, J.W.; Smith, D.; Steward, W.; Harper, P.G.; Dunn, J.; Tudur-Smith, C.; West, J.; et al. Phase III randomized comparison of gemcitabine versus gemcitabine plus capecitabine in patients with advanced pancreatic cancer. J. Clin. Oncol. 2009, 27, 5513-5518. [CrossRef] [PubMed]

5. Von Hoff, D.D.; Ervin, T.; Arena, F.P.; Chiorean, E.G.; Infante, J.; Moore, M.; Seay, T.; Tjulandin, S.A.; Ma, W.W.; Saleh, M.N.; et al. Increased Survival in Pancreatic Cancer with nab-Paclitaxel plus Gemcitabine. N. Engl. J. Med. 2013, 369, 1691-1703. [CrossRef] [PubMed]

6. Vaccaro, V.; Sperduti, I.; Milella, M. FOLFIRINOX versus gemcitabine for metastatic pancreatic cancer. N. Engl. J. Med. 2011, 365, 768-769. [CrossRef] [PubMed]

7. Bilimoria, K.Y.; Bentrem, D.J.; Ko, C.Y.; Tomlinson, J.S.; Stewart, A.K.; Winchester, D.P.; Talamonti, M.S. Multimodality therapy for pancreatic cancer in the U.S.: Utilization, outcomes, and the effect of hospital volume. Cancer 2007, 110, 1227-1234. [CrossRef] [PubMed]

8. Sohal, D.P.S.; Walsh, R.M.; Ramanathan, R.K.; Khorana, A.A. Pancreatic adenocarcinoma: Treating a systemic disease with systemic therapy. J. Natl. Cancer Inst. 2014, 106, 10-13. [CrossRef] [PubMed]

9. Bischoff, J.R.; Kirn, D.H.; Williams, A.; Heise, C.; Horn, S.; Muna, M.; Ng, L.; Nye, J.A.; Sampson-Johannes, A.; Fattaey, A.; et al. An Adenovirus Mutant That Replicates Selectively in p53- Deficient Human Tumor Cells. Science 1996, 274, 373-376. [CrossRef] [PubMed] 
10. Kawashima, T.; Kagawa, S.; Kobayashi, N.; Shirakiya, Y.; Umeoka, T.; Teraishi, F.; Taki, M.; Kyo, S.; Tanaka, N.; Fujiwara, T. Telomerase-specific replication-selective virotherapy for human cancer. Clin. Cancer Res. 2004, 10, 285-292. [CrossRef] [PubMed]

11. Huch, M.; Gros, A.; José, A.; González, J.R.; Alemany, R.; Fillat, C. Urokinase-type plasminogen activator receptor transcriptionally controlled adenoviruses eradicate pancreatic tumors and liver metastasis in mouse models. Neoplasia 2009, 11, 518-528. [CrossRef] [PubMed]

12. Sobrevals, L.; Mato-Berciano, A.; Urtasun, N.; Mazo, A.; Fillat, C. uPAR-controlled oncolytic adenoviruses eliminate cancer stem cells in human pancreatic tumors. Stem Cell Res. 2014, 12, 1-10. [CrossRef] [PubMed]

13. Yamamoto, M.; Davydova, J.; Wang, M.; Siegal, G.P.; Krasnykh, V.; Vickers, S.M.; Curiel, D.T. Infectivity enhanced, cyclooxygenase-2 promoter-based conditionally replicative adenovirus for pancreatic cancer. Gastroenterology 2003, 125, 1203-1218. [CrossRef]

14. Miura, Y.; Yamasaki, S.; Davydova, J.; Brown, E.; Aoki, K.; Vickers, S.; Yamamoto, M. Infectivity-selective oncolytic adenovirus developed by high-throughput screening of adenovirus-formatted library. Mol. Ther. 2013, 21, 139-148. [CrossRef] [PubMed]

15. Frierson, H.F.; Moskaluk, C.A.; Powell, S.M.; Zhang, H.; Cerilli, L.A.; Stoler, M.H.; Cathro, H.; Hampton, G.M.; Kojima, T.; Oh-eda, M.; et al. Large-scale molecular and tissue microarray analysis of mesothelin expression in common human carcinomas. Hum. Pathol. 2003, 34, 605-609. [CrossRef]

16. Yamamoto, Y.; Goto, N.; Miura, K.; Narumi, K.; Ohnami, S.; Uchida, H.; Miura, Y.; Yamamoto, M.; Aoki, K. Development of a Novel Efficient Method To Construct an Adenovirus Library Displaying Random Peptides on the Fiber Knob. Mol. Pharm. 2014, 11, 1069-1074. [CrossRef] [PubMed]

17. Andtbacka, R.H.I.; Kaufman, H.L.; Collichio, F.; Amatruda, T.; Senzer, N.; Chesney, J.; Delman, K.A.; Spitler, L.E.; Puzanov, I.; Agarwala, S.S.; et al. Talimogene Laherparepvec Improves Durable Response Rate in Patients With Advanced Melanoma. J. Clin. Oncol. 2015, 33, 2780-2788. [CrossRef] [PubMed]

18. Mahalingam, D.; Patel, S.; Nuovo, G.; Gill, G.; Selvaggi, G.; Coffey, M.; Nawrocki, S.T. The combination of intravenous Reolysin and gemcitabine induces reovirus replication and endoplasmic reticular stress in a patient with KRAS-activated pancreatic cancer. BMC Cancer 2015, 15, 513. [CrossRef] [PubMed]

19. Nakao, A.; Kasuya, H.; Sahin, T.T.; Nomura, N.; Kanzaki, A.; Misawa, M.; Shirota, T.; Yamada, S.; Fujii, T.; Sugimoto, H.; et al. A phase I dose-escalation clinical trial of intraoperative direct intratumoral injection of HF10 oncolytic virus in non-resectable patients with advanced pancreatic cancer. Cancer Gene Ther. 2011, 18, 167-175. [CrossRef] [PubMed]

20. Eissa, I.R.; Naoe, Y.; Bustos-Villalobos, I.; Ichinose, T.; Tanaka, M.; Zhiwen, W.; Mukoyama, N.; Morimoto, T.; Miyajima, N.; Hitoki, H.; et al. Genomic Signature of the Natural Oncolytic Herpes Simplex Virus HF10 and Its Therapeutic Role in Preclinical and Clinical Trials. Front. Oncol. 2017, 7, 149. [CrossRef] [PubMed]

21. Rodriguez-Garcia, A.; Gimenez-Alejandre, M.; Rojas, J.J.; Moreno, R.; Bazan-Peregrino, M.; Cascallo, M.; Alemany, R. Safety and Efficacy of VCN-01, an Oncolytic Adenovirus Combining Fiber HSG-Binding Domain Replacement with RGD and Hyaluronidase Expression. Clin. Cancer Res. 2015, 21, 1406-1418. [CrossRef] [PubMed]

22. Eriksson, E.; Milenova, I.; Wenthe, J.; Ståhle, M.; Leja-Jarblad, J.; Ullenhag, G.; Dimberg, A.; Moreno, R.; Alemany, R.; Loskog, A. Shaping the Tumor Stroma and Sparking Immune Activation by CD40 and 4-1BB Signaling Induced by an Armed Oncolytic Virus. Clin. Cancer Res. 2017, 23, 5846-5857. [CrossRef] [PubMed]

23. Alberts, S.R.; Schroeder, M.; Erlichman, C.; Steen, P.D.; Foster, N.R.; Moore, D.F.; Rowland, K.M.; Nair, S.; Tschetter, L.K.; Fitch, T.R. Gemcitabine and ISIS-2503 for patients with locally advanced or metastatic pancreatic adenocarcinoma: A north central cancer treatment group phase II trial. J. Clin. Oncol. 2004, 22, 4944-4950. [CrossRef] [PubMed]

24. Adjei, A.A.; Dy, G.K.; Erlichman, C.; Reid, J.M.; Sloan, J.A.; Pitot, H.C.; Alberts, S.R.; Goldberg, R.M.; Hanson, L.J.; Atherton, P.J.; et al. A phase I trial of ISIS 2503, an antisense inhibitor of H-ras, in combination with gemcitabine in patients with advanced cancer. Clin. Cancer Res. 2003, 9, 115-123. [PubMed]

25. Mahadevan, D.; Chalasani, P.; Rensvold, D.; Kurtin, S.; Pretzinger, C.; Jolivet, J.; Ramanathan, R.K.; Von Hoff, D.D.; Weiss, G.J. Phase I Trial of AEG35156 an Antisense Oligonucleotide to XIAP Plus Gemcitabine in Patients With Metastatic Pancreatic Ductal Adenocarcinoma. Am. J. Clin. Oncol. 2013, 36, 239-243. [CrossRef] [PubMed] 
26. Aleku, M.; Schulz, P.; Keil, O.; Santel, A.; Schaeper, U.; Dieckhoff, B.; Janke, O.; Endruschat, J.; Durieux, B.; Röder, N.; et al. Atu027, a liposomal small interfering RNA formulation targeting protein kinase N3, inhibits cancer progression. Cancer Res. 2008, 68, 9788-9798. [CrossRef] [PubMed]

27. Leenders, F.; Möpert, K.; Schmiedeknecht, A.; Santel, A.; Czauderna, F.; Aleku, M.; Penschuck, S.; Dames, S.; Sternberger, M.; Röhl, T.; et al. PKN3 is required for malignant prostate cell growth downstream of activated PI 3-kinase. EMBO J. 2004, 23, 3303-3313. [CrossRef] [PubMed]

28. Golan, T.; Khvalevsky, E.Z.; Hubert, A.; Gabai, R.M.; Hen, N.; Segal, A.; Domb, A.; Harari, G.; David, E.B.; Raskin, S.; et al. RNAi therapy targeting KRAS in combination with chemotherapy for locally advanced pancreatic cancer patients. Oncotarget 2015, 6, 24560-24570. [CrossRef] [PubMed]

29. Buscail, L.; Bournet, B.; Vernejoul, F.; Cambois, G.; Lulka, H.; Hanoun, N.; Dufresne, M.; Meulle, A.; Vignolle-Vidoni, A.; Ligat, L.; et al. First-in-man phase 1 clinical trial of gene therapy for advanced pancreatic cancer: Safety, biodistribution, and preliminary clinical findings. Mol. Ther. 2015, 23, 779-789. [CrossRef] [PubMed]

30. Carrere, N.; Vernejoul, F.; Souque, A.; Asnacios, A.; Vaysse, N.; Pradayrol, L.; Susini, C.; Buscail, L.; Cordelier, P. Characterization of the bystander effect of somatostatin receptor sst2 after in vivo gene transfer into human pancreatic cancer cells. Hum. Gene Ther. 2005, 16, 1175-1193. [CrossRef] [PubMed]

31. Hanna, N.; Ohana, P.; Konikoff, F.M.; Leichtmann, G.; Hubert, A.; Appelbaum, L.; Kopelman, Y.; Czerniak, A.; Hochberg, A. Phase 1/2a, dose-escalation, safety, pharmacokinetic and preliminary efficacy study of intratumoral administration of BC-819 in patients with unresectable pancreatic cancer. Cancer Gene Ther. 2012, 19, 374-381. [CrossRef] [PubMed]

32. Senzer, N.; Nemunaitis, J.; Nemunaitis, D.; Bedell, C.; Edelman, G.; Barve, M.; Nunan, R.; Pirollo, K.F.; Rait, A.; Chang, E.H. Phase i study of a systemically delivered p53 nanoparticle in advanced solid tumors. Mol. Ther. 2013, 21, 1096-1103. [CrossRef] [PubMed]

33. Killock, D. Skin cancer: T-VEC oncolytic viral therapy shows promise in melanoma. Nat. Rev. Clin. Oncol. 2015, 12, 438. [CrossRef] [PubMed]

34. Yamamoto, M.; Curiel, D.T. Current issues and future directions of oncolytic adenoviruses. Mol. Ther. 2010, 18, 243-250. [CrossRef] [PubMed]

35. Alemany, R.; Balagué, C.; Curiel, D.T. Replicative adenoviruses for cancer therapy. Nat. Biotechnol. 2000, 18, 723-727. [CrossRef] [PubMed]

36. Liebert, M.A.; Hallenbeck, P.L.; Chang, Y.; Hay, C.; Golightly, D.; Art, D.S.; Lin, J.; Phipps, S.; Chiang, Y.L. A novel tumor-specific replication-restricted adenoviral vector for gene therapy of hepatocellular carcinoma. Hum. Gene Ther. 1999, 10, 1721-1733.

37. Shenk, T. Adenoviridae: The viruses and their replication. In Virology; Fields, B., Knipe, D., Howley, P., Eds.; Lipponcott-Raven: Philadelphia, PA, USA, 1996; Volume 2, pp. 2111-2148.

38. Rodriguez-Rocha, H.; Gomez-Gutierrez, J.G.; Garcia-Garcia, A.; Rao, X.-M.; Chen, L.; McMasters, K.M.; Zhou, H.S. Adenoviruses induce autophagy to promote virus replication and oncolysis. Virology 2011, 416, 9-15. [CrossRef] [PubMed]

39. Heise, C.; Hermiston, T.; Johnson, L.; Brooks, G.; Sampson-Johannes, A.; Williams, A.; Hawkins, L.; Kirn, D. An adenovirus E1A mutant that demonstrates potent and selective systemic anti-tumoral efficacy. Nat. Med. 2000, 6, 1134-1139. [CrossRef] [PubMed]

40. Fueyo, J.; Gomez-Manzano, C.; Alemany, R.; Lee, P.S.; McDonnell, T.J.; Mitlianga, P.; Shi, Y.X.; Levin, V.A.; Yung, W.K.; Kyritsis, A.P. A mutant oncolytic adenovirus targeting the Rb pathway produces anti-glioma effect in vivo. Oncogene 2000, 19, 2-12. [CrossRef] [PubMed]

41. Zheng, X.; Rao, X.-M.; Gomez-Gutierrez, J.G.; Hao, H.; McMasters, K.M.; Zhou, H.S. Adenovirus E1B55K region is required to enhance cyclin E expression for efficient viral DNA replication. J. Virol. 2008, 82, 3415-3427. [CrossRef] [PubMed]

42. LaRocca, C.J.; Han, J.; Salzwedel, A.O.; Davydova, J.; Herzberg, M.C.; Gopalakrishnan, R.; Yamamoto, M. Oncolytic adenoviruses targeted to Human Papilloma Virus-positive head and neck squamous cell carcinomas. Oral Oncol. 2016, 56, 25-31. [CrossRef] [PubMed]

43. Davydova, J.; Le, L.P.; Gavrikova, T.; Wang, M.; Krasnykh, V.; Yamamoto, M. Infectivity-enhanced cyclooxygenase-2-based conditionally replicative adenoviruses for esophageal adenocarcinoma treatment. Cancer Res. 2004, 64, 4319-4327. [CrossRef] [PubMed] 
44. Kosaka, T.; Davydova, J.; Ono, H.A.; Akiyama, H.; Hirai, S.I.; Ohno, S.; Takeshita, F.; Aoki, K.; Ochiya, T.; Yamamoto, M.; et al. Imaging and antitumoral effect of a cyclo-oxygenase 2-specific replicative adenovirus for small metastatic gastric cancer lesions. Anticancer Res. 2015, 35, 5201-5210. [PubMed]

45. Wesseling, J.G.; Bosma, P.J.; Krasnykh, V.; Kashentseva, E.A.; Blackwell, J.L.; Reynolds, P.N.; Li, H.; Parameshwar, M.; Vickers, S.M.; Jaffee, E.M.; et al. Improved gene transfer efficiency to primary and established human pancreatic carcinoma target cells via epidermal growth factor receptor and integrin-targeted adenoviral vectors. Gene Ther. 2001, 8, 969-976. [CrossRef] [PubMed]

46. Krasnykh, V.; Dmitriev, I.; Mikheeva, G.; Miller, C.R.; Belousova, N.; Curiel, D.T. Characterization of an adenovirus vector containing a heterologous peptide epitope in the HI loop of the fiber knob. J. Virol. 1998, 72, 1844-1852. [PubMed]

47. Dmitriev, I.; Kashentseva, E.; Rogers, B.E.; Krasnykh, V.; Curiel, D.T. Ectodomain of coxsackievirus and adenovirus receptor genetically fused to epidermal growth factor mediates adenovirus targeting to epidermal growth factor receptor-positive cells. J. Virol. 2000, 74, 6875-6884. [CrossRef] [PubMed]

48. Yao, V.J.; Ozawa, M.G.; Varner, A.S.; Kasman, I.M.; Chanthery, Y.H.; Pasqualini, R.; Arap, W.; McDonald, D.M. Antiangiogenic Therapy Decreases Integrin Expression in Normalized Tumor Blood Vessels. Cancer Res. 2006, 2639-2649. [CrossRef] [PubMed]

49. Ramírez, P.J.; Vickers, S.M.; Ono, H.A.; Davydova, J.; Takayama, K.; Thompson, T.C.; Curiel, D.T.; Bland, K.I.; Yamamoto, M. Optimization of conditionally replicative adenovirus for pancreatic cancer and its evaluation in an orthotopic murine xenograft model. Am. J. Surg. 2008, 195, 481-490. [CrossRef] [PubMed]

50. Gaggar, A.; Shayakhmetov, D.M.; Liszewski, M.K.; Atkinson, J.P.; Lieber, A. Localization of regions in CD46 that interact with adenovirus. J. Virol. 2005, 79, 7503-7513. [CrossRef] [PubMed]

51. Sirena, D.; Lilienfeld, B.; Eisenhut, M.; Kälin, S.; Boucke, K.; Beerli, R.R.; Vogt, L.; Ruedl, C.; Bachmann, M.F.; Greber, U.F.; Hemmi, S. The human membrane cofactor CD46 is a receptor for species B adenovirus serotype 3. J. Virol. 2004, 78, 4454-4462. [CrossRef] [PubMed]

52. Curiel, D.T. Strategies to adapt adenoviral vectors for targeted delivery. Gene Ther. 1999, 886, $158-171$. [CrossRef]

53. Tanaka, T. Carcinoembryonic Antigen-Targeted Selective Gene Therapy for Gastric Cancer through FZ33 Fiber-Modified Adenovirus Vectors. Clin. Cancer Res. 2006, 12, 3803-3813. [CrossRef] [PubMed]

54. Douglas, J.T.; Rogers, B.E.; Rosenfeld, M.E.; Michael, S.I.; Feng, M.; Curiel, D.T. Targeted gene delivery by tropism-modified adenoviral vectors. Nat. Biotechnol. 1996, 14, 303-308. [CrossRef] [PubMed]

55. Liu, Y.; Wang, H.; Yumul, R.; Gao, W.; Gambotto, A.; Morita, T.; Baker, A.; Shayakhmetov, D.; Lieber, A. Transduction of liver metastases after intravenous injection of Ad5/35 or Ad35 vectors with and without factor X-binding protein pretreatment. Hum. Gene Ther. 2009, 20, 621-629. [CrossRef] [PubMed]

56. Liikanen, I.; Monsurrò, V.; Ahtiainen, L.; Raki, M.; Hakkarainen, T.; Diaconu, I.; Escutenaire, S.; Hemminki, O.; Dias, J.D.; Cerullo, V.; et al. Induction of Interferon Pathways Mediates In Vivo Resistance to Oncolytic Adenovirus. Mol. Ther. 2011, 19, 1858-1866. [CrossRef] [PubMed]

57. Koski, A.; Kangasniemi, L.; Escutenaire, S.; Pesonen, S.; Cerullo, V.; Diaconu, I.; Nokisalmi, P.; Raki, M.; Rajecki, M.; Guse, K.; et al. Treatment of cancer patients with a serotype 5/3 chimeric oncolytic adenovirus expressing GMCSF. Mol. Ther. 2010, 18, 1874-1884. [CrossRef] [PubMed]

58. Kuhn, I.; Harden, P.; Bauzon, M.; Chartier, C.; Nye, J.; Thorne, S.; Reid, T.; Ni, S.; Lieber, A.; Fisher, K.; et al. Directed evolution generates a novel oncolytic virus for the treatment of colon cancer. PLOS ONE 2008, 3, e2409. [CrossRef] [PubMed]

59. Di, Y.; Seymour, L.; Fisher, K. Activity of a group B oncolytic adenovirus (ColoAd1) in whole human blood. Gene Ther. 2014, 21, 440-443. [CrossRef] [PubMed]

60. Boni, V.; De La Portilla, F.; Cubillo, A.; Gil-Martin, M.; Calvo, E.; Salazar, R.; Santos, C.; Sanchez-Gastaldo, A.; Prados, S.; Sanjuan, X.; et al. 1068P A Phase 1 mechanism of action study of intra-tumoural (IT) or intravenous (IV) administration of enadenotucirev, an oncolytic Ad11/Ad3 chimeric group b adenovirus in colon cancer patients undergoing resection of primary tumour. Ann. Oncol. 2014, 25, iv368. [CrossRef]

61. Joung, I.; Harber, G.; Gerecke, K.M.; Carroll, S.L.; Collawn, J.F.; Engler, J.A. Improved gene delivery into neuroglial cells using a fiber-modified adenovirus vector. Biochem. Biophys. Res. Commun. 2005, 328, 1182-1187. [CrossRef] [PubMed]

62. Nicklin, S. Ablating Adenovirus Type 5 Fiber-CAR Binding and HI Loop Insertion of the SIGYPLP Peptide Generate an Endothelial Cell-Selective Adenovirus. Mol. Ther. 2001, 4, 534-542. [CrossRef] [PubMed] 
63. Laakkonen, P.; Porkka, K.; Hoffman, J.A.; Ruoslahti, E. A tumor-homing peptide with a targeting specificity related to lymphatic vessels. Nat. Med. 2002, 751-755. [CrossRef] [PubMed]

64. Nishimoto, T.; Yoshida, K.; Miura, Y.; Kobayashi, A.; Hara, H.; Ohnami, S.; Kurisu, K.; Yoshida, T.; Aoki, K. Oncolytic virus therapy for pancreatic cancer using the adenovirus library displaying random peptides on the fiber knob. Gene Ther. 2009, 16, 669-680. [CrossRef] [PubMed]

65. Shashkova, E.V.; Kuppuswamy, M.N.; Wold, W.S.M.; Doronin, K. Anticancer activity of oncolytic adenovirus vector armed with IFN- $\alpha$ and ADP is enhanced by pharmacologically controlled expression of TRAIL. Cancer Gene Ther. 2008, 15, 61-72. [CrossRef] [PubMed]

66. Kim, J.H.; Oh, J.Y.; Park, B.H.; Lee, D.E.; Kim, J.S.; Park, H.E.; Roh, M.S.; Je, J.E.; Yoon, J.H.; Thorne, S.H.; et al. Systemic Armed Oncolytic and Immunologic Therapy for Cancer with JX-594, a Targeted Poxvirus Expressing GM-CSF. Mol. Ther. 2006, 14, 361-370. [CrossRef] [PubMed]

67. Nukui, Y.; Picozzi, V.J.; Traverso, L.W. Interferon-based adjuvant chemoradiation therapy improves survival after pancreaticoduodenectomy for pancreatic adenocarcinoma. Am. J. Surg. 2000, 179, 367-371. [CrossRef]

68. Schmidt, J.; Patrut, E.M.; Ma, J.; Jäger, D.; Knaebel, H.-P.; Büchler, M.W.; Märten, A. Immunomodulatory impact of interferon- $\alpha$ in combination with chemoradiation of pancreatic adenocarcinoma (CapRI). Cancer Immunol. Immunother. 2006, 55, 1396-1405. [CrossRef] [PubMed]

69. Talpaz, M.; Chernajovsky, Y.; Troutman Worden, K.; Wetzler, M.; Kantarjian, H.; Gutterman, J.U.; Kurzrock, R. Interferon-stimulated genes in interferon-sensitive and -resistant chronic myelogenous leukemia patients. Cancer Res 1992, 52, 1087-1090. [PubMed]

70. Holsti, L.R.; Mattson, K.; Niiranen, A.; Standertskiöld-Nordenstam, C.-G.; Stenman, S.; Sovijärvi, A.; Cantell, K. Enhancement of radiation effects by $\alpha$ interferon in the treatment of small cell carcinoma of the lung. Int. J. Radiat. Oncol. 1987, 13, 1161-1166. [CrossRef]

71. Feig, C.; Gopinathan, A.; Neesse, A.; Chan, D.S.; Cook, N.; Tuveson, D.A. The pancreas cancer microenvironment. Clin. Cancer Res. 2012, 18, 4266-4276. [CrossRef] [PubMed]

72. Rodallec, M.; Vilgrain, V.; Couvelard, A.; Rufat, P.; O'Toole, D.; Barrau, V.; Sauvanet, A.; Ruszniewski, P.; Menu, Y. Endocrine Pancreatic Tumours and Helical CT: Contrast Enhancement Is Correlated with Microvascular Density, Histoprognostic Factors and Survival. Pancreatology 2006, 6, 77-85. [CrossRef] [PubMed]

73. LaRocca, C.J.; Han, J.; Gavrikova, T.; Armstrong, L.; Oliveira, A.R.; Shanley, R.; Vickers, S.M.; Yamamoto, M.; Davydova, J. Oncolytic adenovirus expressing interferon $\alpha$ in a syngeneic Syrian hamster model for the treatment of pancreatic cancer. Surgery 2015, 157, 888-898. [CrossRef] [PubMed]

74. Cerullo, V.; Pesonen, S.; Diaconu, I.; Escutenaire, S.; Arstila, P.T.; Ugolini, M.; Nokisalmi, P.; Raki, M.; Laasonen, L.; Särkioja, M.; et al. Oncolytic adenovirus coding for granulocyte macrophage colony-stimulating factor induces antitumoral immunity in cancer patients. Cancer Res. 2010, 70, 4297-4309. [CrossRef] [PubMed]

75. Poutou, J.; Bunuales, M.; Gonzalez-Aparicio, M.; Garcia-Aragoncillo, E.; Quetglas, J.I.; Casado, R.; Bravo-Perez, C.; Alzuguren, P.; Hernandez-Alcoceba, R. Safety and antitumor effect of oncolytic and helper-dependent adenoviruses expressing interleukin-12 variants in a hamster pancreatic cancer model. Gene Ther. 2015, 22, 696-706. [CrossRef] [PubMed]

76. Loskog, A. Immunostimulatory gene therapy using oncolytic viruses as vehicles. Viruses 2015, 7, 5780-5791. [CrossRef] [PubMed]

77. Reboul, F.; Serin, D.; Martin, D.P.F. Combination radiotherapy and chemotherapy in cancer of the pancreas. Review of the literature and prospects. Bull Cancer 1990, 77, 275-281. [PubMed]

78. Noordhuis, M.G.; Eijsink, J.J.H.; Roossink, F.; de Graeff, P.; Pras, E.; Schuuring, E.; Wisman, G.B.A.; de Bock, G.H.; van der Zee, A.G.J. Prognostic Cell Biological Markers in Cervical Cancer Patients Primarily Treated With (Chemo)radiation: A Systematic Review. Int. J. Radiat. Oncol. 2011, 79, 325-334. [CrossRef] [PubMed]

79. Whistance, R.N.; Blazeby, J.M. Systematic review: Quality of life after treatment for upper gastrointestinal cancer. Curr. Opin. Support. Palliat. Care 2011, 5, 37-46. [CrossRef] [PubMed]

80. Leitner, S.; Sweeney, K.; Oberg, D.; Davies, D.; Miranda, E.; Lemoine, N.R.; Hallden, G. Oncolytic Adenoviral Mutants with E1B19K Gene Deletions Enhance Gemcitabine-induced Apoptosis in Pancreatic Carcinoma Cells and Anti- Tumor Efficacy In vivo. Clin. Cancer Res. 2009, 15, 1730-1740. [CrossRef] [PubMed] 
81. Raki, M.; Kanerva, A.; Ristimaki, A.; Desmond, R.A.; Chen, D.-T.; Ranki, T.; Sarkioja, M.; Kangasniemi, L. Hemminki, a Combination of gemcitabine and Ad5/3-Delta24, a tropism modified conditionally replicating adenovirus, for the treatment of ovarian cancer. Gene Ther. 2005, 12, 1198-1205. [CrossRef] [PubMed]

82. Dias, J.D.; Hemminki, O.; Diaconu, I.; Hirvinen, M.; Bonetti, A.; Guse, K.; Escutenaire, S.; Kanerva, A.; Pesonen, S.; Löskog, A.; et al. Targeted cancer immunotherapy with oncolytic adenovirus coding for a fully human monoclonal antibody specific for CTLA-4. Gene Ther. 2012, 19, 988-998. [CrossRef] [PubMed]

83. Yin, H.; Kanasty, R.L.; Eltoukhy, A.A.; Vegas, A.J.; Dorkin, J.R.; Anderson, D.G. Non-viral vectors for gene-based therapy. Nat. Rev. Genet. 2014, 15, 541-555. [CrossRef] [PubMed]

84. Dowdy, S.F. Overcoming cellular barriers for RNA therapeutics. Nat. Biotechnol. 2017, 35, 222-229. [CrossRef] [PubMed]

85. Schultheis, B.; Strumberg, D.; Santel, A.; Vank, C.; Gebhardt, F.; Keil, O.; Lange, C.; Giese, K.; Kaufmann, J.; Khan, M.; et al. First-in-human phase I study of the liposomal RNA interference therapeutic Atu027 in patients with advanced solid tumors. J. Clin. Oncol. 2014, 32, 4141-4148. [CrossRef] [PubMed]

86. Kim, H.J.; Kim, A.; Miyata, K.; Kataoka, K. Recent progress in development of siRNA delivery vehicles for cancer therapy. Adv. Drug Deliv. Rev. 2016, 104, 61-77. [CrossRef] [PubMed]

87. Wang, T.; Shigdar, S.; Shamaileh, H.A.; Gantier, M.P.; Yin, W.; Xiang, D.; Wang, L.; Zhou, S.F.; Hou, Y.; Wang, P.; et al. Challenges and opportunities for siRNA-based cancer treatment. Cancer Lett. 2017, 387, 77-83. [CrossRef] [PubMed]

88. Jinek, M.; Doudna, J.A. A three-dimensional view of the molecular machinery of RNA interference. Nature 2009, 457, 405-412. [CrossRef] [PubMed]

89. Barata, P.; Sood, A.K.; Hong, D.S. RNA-targeted therapeutics in cancer clinical trials: Current status and future directions. Cancer Treat. Rev. 2016, 50, 35-47. [CrossRef] [PubMed]

90. Ying, H.; Dey, P.; Yao, W.; Kimmelman, A.C.; Draetta, G.F.; Maitra, A.; DePinho, R.A. Genetics and biology of pancreatic ductal adenocarcinoma. Genes Dev. 2016, 30, 355-385. [CrossRef] [PubMed]

91. Cabral, H.; Matsumoto, Y.; Mizuno, K.; Chen, Q.; Murakami, M.; Kimura, M.; Terada, Y.; Kano, M.R.; Miyazono, K.; Uesaka, M.; et al. Accumulation of sub-100 nm polymeric micelles in poorly permeable tumours depends on size. Nat. Nanotechnol. 2011, 6, 815-823. [CrossRef] [PubMed]

92. Khvorova, A.; Watts, J.K. The chemical evolution of oligonucleotide therapies of clinical utility. Nat. Biotechnol. 2017, 35, 238-248. [CrossRef] [PubMed]

93. Choi, M.; Bien, H.; Mofunanya, A.; Powers, S. Challenges in Ras therapeutics in pancreatic cancer. Semin. Cancer Biol. 2017. [CrossRef] [PubMed]

94. Yang, L.; Cao, Z.; Yan, H. Coexistence of High Levels of Apoptotic Signaling and Inhibitor of Apoptosis Proteins in Human Tumor Cells. Cancer Res. 2003, 63, 6815-6824. [PubMed]

95. Mohammed, A.; Janakiram, N.B.; Pant, S.; Rao, C.V. Molecular targeted intervention for pancreatic cancer. Cancers (Basel) 2015, 7, 1499-1542. [CrossRef] [PubMed]

96. Zorde Khvalevsky, E.; Gabai, R.; Rachmut, I.H.; Horwitz, E.; Brunschwig, Z.; Orbach, A.; Shemi, A.; Golan, T.; Domb, A.J.; Yavin, E.; et al. Mutant KRAS is a druggable target for pancreatic cancer. Proc. Natl. Acad. Sci. USA 2013, 110, 20723-20728. [CrossRef] [PubMed]

97. He, L.; Hannon, G.J. MicroRNAs: Small RNAs with a big role in gene regulation. Nat. Rev. Genet. 2004, 5, 522-531. [CrossRef] [PubMed]

98. Merhautova, J.; Demlova, R.; Slaby, O. MicroRNA-based therapy in animal models of selected gastrointestinal cancers. Front. Pharmacol. 2016, 7. [CrossRef] [PubMed]

99. Karmakar, S.; Kaushik, G.; Nimmakayala, R.; Rachagani, S.; Ponnusamy, M.P.; Batra, S.K. MicroRNA regulation of K-Ras in pancreatic cancer and opportunities for therapeutic intervention. Semin. Cancer Biol. 2017. [CrossRef] [PubMed]

100. Scholz, C.; Wagner, E. Therapeutic plasmid DNA versus siRNA delivery: Common and different tasks for synthetic carriers. J. Control. Release 2012, 161, 554-565. [CrossRef] [PubMed]

101. Amrutkar, M.; Gladhaug, I.P. Pancreatic cancer chemoresistance to gemcitabine. Cancers (Basel) 2017, 9, 157. [CrossRef] [PubMed]

102. Buscail, L.; Saint-Laurent, N.; Chastre, E.; Vaillant, J.C.; Gespach, C.; Capella, G.; Kalthoff, H.; Lluis, F.; Vaysse, N.; Susini, C. Loss of sst2 somatostatin receptor gene expression in human pancreatic and colorectal cancer. Cancer Res. 1996, 56, 1823-1827. [PubMed] 
103. Ohhashi, S.; Ohuchida, K.; Mizumoto, K.; Fujita, H.; Egami, T.; Yu, J.; Toma, H.; Sadatomi, S.; Nagai, E.; Tanaka, M. Down-regulation of deoxycytidine kinase enhances acquired resistance to gemcitabine in pancreatic cancer. Anticancer Res. 2008, 28, 2205-2212. [PubMed]

104. Ohana, P.; Bibi, O.; Matouk, I.; Levy, C.; Birman, T.; Ariel, I.; Schneider, T.; Ayesh, S.; Giladi, H.; Laster, M.; et al. Use of H19 regulatory sequences for targeted gene therapy in cancer. Int. J. Cancer 2002, 98, 645-650. [CrossRef] [PubMed]

105. Ventura, A.; Kirsch, D.G.; McLaughlin, M.E.; Tuveson, D.A.; Grimm, J.; Lintault, L.; Newman, J.; Reczek, E.E.; Weissleder, R.; Jacks, T. Restoration of p53 function leads to tumour regression in vivo. Nature 2007, 445, 661-665. [CrossRef] [PubMed]

106. Xu, L.; Tang, W.-H.; Huang, C.-C.; Alexander, W.; Xiang, L.-M.; Pirollo, K.F.; Rait, A.; Chang, E.H. Systemic p53 Gene Therapy of Cancer with Immunolipoplexes Targeted by Anti-Transferrin Receptor scFv. Mol. Med. 2001, 7, 723-734. [PubMed]

107. Deltcheva, E.; Chylinski, K.; Sharma, C.M.; Gonzales, K. CRISPR RNA maturation by trans -encoded small RNA and host factor RNase III. Nature 2011, 471, 602-607. [CrossRef] [PubMed]

108. Maresch, R.; Mueller, S.; Veltkamp, C.; Öllinger, R.; Friedrich, M.; Heid, I.; Steiger, K.; Weber, J.; Engleitner, T.; Barenboim, M.; et al. Multiplexed pancreatic genome engineering and cancer induction by transfection-based CRISPR/Cas9 delivery in mice. Nat. Commun. 2016, 7. [CrossRef] [PubMed]

109. Vorvis, C.; Hatziapostolou, M.; Mahurkar-Joshi, S.; Koutsioumpa, M.; Williams, J.; Donahue, T.R.; Poultsides, G.A.; Eibl, G.; Iliopoulos, D. Transcriptomic and CRISPR/Cas9 technologies reveal FOXA2 as a tumor suppressor gene in pancreatic cancer. Am. J. Physiol. Gastrointest. Liver Physiol. 2016, 310, G1124-G1137. [CrossRef] [PubMed]

110. Cyranoski, D. CRISPR gene editing tested in a person. Nature 2016, 539, 479. [CrossRef] [PubMed]

111. Liu, C.; Zhang, L.; Liu, H.; Cheng, K. Delivery strategies of the CRISPR-Cas9 gene-editing system for therapeutic applications. J. Control. Release 2017, 266, 17-26. [CrossRef] [PubMed]

112. Glass, Z.; Lee, M.; Li, Y.; Xu, Q. Engineering the Delivery System for CRISPR-Based Genome Editing. Trends Biotechnol. 2018, 36, 173-185. [CrossRef] [PubMed]

113. Rahib, L.; Smith, B.D.; Aizenberg, R.; Rosenzweig, A.B.; Fleshman, J.M.; Matrisian, L.M. Projecting cancer incidence and deaths to 2030: The unexpected burden of thyroid, liver, and pancreas cancers in the united states. Cancer Res. 2014, 74, 2913-2921. [CrossRef] [PubMed] 